\title{
Thermal Stabilization of HEWL by Adsorption on Biochar
}

\author{
Hidetaka Noritomi ${ }^{1}$, Ryotaro Kai ${ }^{1}$, Nobuyuki Endo ${ }^{2}$, Satoru Kato ${ }^{1} \&$ Katsumi Uchiyama ${ }^{1}$ \\ ${ }^{1}$ Department of Applied Chemistry for Environment, Tokyo Metropolitan University, Tokyo, Japan \\ ${ }^{2}$ EEN Co., Ltd., Tokyo, Japan \\ Correspondence: Hidetaka Noritomi, Department of Applied Chemistry for Environment, Tokyo Metropolitan \\ University, Tokyo, 192-0397, Japan. Tel: 81-42-677-2824. E-mail: noritomi@tmu.ac.jp
}

Received: September 3, 2019

Accepted: September 26, 2019 Online Published: September 30, 2019

doi:10.5539/jmsr.v8n4p30

URL: https://doi.org/10.5539/jmsr.v8n4p30

\begin{abstract}
We have found that the heat stress tolerance of hen egg white lysozyme (HEWL) is markedly enhanced by the adsorption of HEWL on bamboo charcoal powder (BCP), which is a kind of biochar. HEWL was firmly adsorbed on BCP even at high temperatures. The secondary structure of HEWL was altered to some extent by the adsorption of HEWL on BCP. The remaining activity of BCP-adsorbed HEWL exhibited more than $20 \%$ after the incubation for $30 \mathrm{~min}$ at $90^{\circ} \mathrm{C}$ although that of free one was hardly observed. Moreover, the half-life of BCP-adsorbed HEWL was $13 \mathrm{~min}$ at $90^{\circ} \mathrm{C}$ while that of free one was $4 \mathrm{~min}$.
\end{abstract}

Keywords: Adsorption, Biochar, Hen Egg White Lysozyme, Thermal Stabilization

\section{Introduction}

The application of biomass materials, which are carbon neutral, to energies and functional materials is crucial to resolve serious global warming problems since conventional industrial processes tend to produce greenhouse gases such as $\mathrm{CO}_{2}$ (Straathof, 2014; IPCC, 2014; Olivier et al., 2017). However, forestry residues have scarcely been utilized in the industrial field although an enormous amount of forestry residues has been discharged in the world. Accordingly, the development in the high value-added application of forestry residues has been desired to provide the multiple effective utilization system of forestry residues.

Bioprocesses such as biotransformation, biosensor, biofuel cell, and so on have been widely studied as sustainable processes (Heinzle et al., 2006). Bioprocesses have generally utilized enzymes, which are biocatalysts that exhibit outstanding biological activity and specificity under mild conditions (Sheldon \& Woodley, 2018; Buchholz et al., 2012; Leech et al., 2012; Silwana et al., 2014). Enzymes are generally stable in a cell. However, they are gradually denatured and inactivated under various physical and chemical stresses such as heat, organic solvents, and so on (Bailey \& Ollas, 1986). Moreover, enzymes are expensive since they are obtained from living bodies by complicated separation processes. In order to enhance the stability of enzymes used in vitro and recycle enzymes, enzyme immobilization has been carried out mainly by attaching enzymes to solid carriers (Zdata et al., 2018).

In order to apply forestry residues to enzyme carriers, we have so far examined the catalysis of enzymes adsorbed on bamboo charcoal powder (BCP), which was prepared from forestry residues by pyrolysis. We have reported that the adsorption of enzymes on BCP markedly improve the catalytic activity of enzymes in organic solvents (Noritomi et al., 2017a; Noritomi et al., 2017b; Noritomi et al., 2018). In this study, we have examined the stability of enzymes adsorbed on BCP in an aqueous solution at high temperatures. As a model enzyme, hen egg white lysozyme (HEWL) has been employed, since it is well investigated regarding its structure, properties, functions, and applications such as an enzyme-sterilizing filter (Ahern \& Klibanov, 1985; Jollès, 1996; Nohara et al., 1999; Tanaka et al., 2003).

\section{Method}

\subsection{Materials}

Lysozyme from hen egg white (EC 3.2.1.17, 46400 units/mg solid, MW=14300, pI 11) and Micrococcus lysodeikticus (ATCC No. 4698) were purchased from Sigma-Aldrich Co. (St. Louis, USA). 


\subsection{Preparation of Bamboo Charcoal Powder}

To prepare bamboo charcoal as a biochar, under a nitrogen atmosphere, bamboo waste was dried at $180^{\circ} \mathrm{C}$ for $2 \mathrm{~h}$, was pyrolyzed at $450^{\circ} \mathrm{C}$ for $2 \mathrm{~h}$, was carbonized at $350^{\circ} \mathrm{C}$ for $3 \mathrm{~h}$, and then was cooled at $100^{\circ} \mathrm{C}$ for $1 \mathrm{~h}$ by pyrolyzer (EE21 Pyrolyzer, EEN Co. Ltd., Japan) (Noritomi et al., 2017b). Bamboo charcoal powder (BCP) was obtained by grinding the resultant bamboo charcoal with a jet mill (100AS, Fuji Sangyo Co. Ltd., Japan).

\subsection{Characterization of $B C P$}

The SEM micrograph was obtained using a scanning electron microscope (JSM-7500FA, JEOL, Japan) operating at $15 \mathrm{kV}$. The sample for SEM was prepared on a carbon tape without vapor deposition.

All samples were outgassed at $300^{\circ} \mathrm{C}$ for $8 \mathrm{~h}$ prior to the nitrogen adsorption measurements. The specific surface area of BCP was obtained using a micropore system (BELSORP-mini II, BEL JAPAN, INC.), and the pore size distribution was calculated with the use of the micropore analysis method (MP method).

BCP was analyzed by solid-state DD/MAS ${ }^{13} \mathrm{C}-\mathrm{NMR}$ spectroscopy (CMX300 Infinity, Chemagnetics, USA) operating at a ${ }^{13} \mathrm{C}$ resonance frequency of $75.188829 \mathrm{MHz}$ and magic angle spinning (MAS) with spin rate of $10.4 \mathrm{kHz}$.

The surface of BCP was analyzed by X-ray photoelectron spectroscopy (XPS) (Quantum-2000, ULVAC-PHI Co. Ltd.) operating at an X-ray beam size of $100 \mu \mathrm{m}$.

The $\zeta$ potentials of BCP were measured by electrophoretic light scattering (ELS-Z2, OTSUKA Electronics Co. Ltd.).

\subsection{Adsorption of HEWL onto BCP}

As a typical procedure, $0.01 \mathrm{M}$ phosphate buffer solution of $\mathrm{pH} 7$ containing $500 \mu \mathrm{M}$ hen egg white lysozyme (HEWL) and $3 \mathrm{~g} / \mathrm{L} \mathrm{BCP}$ was incubated at $25^{\circ} \mathrm{C}$ and $120 \mathrm{rpm}$ for $24 \mathrm{hr}$. After adsorption, the mixture was filtrated with a membrane filter (pore size: $0.1 \mu \mathrm{m}$, Millipore Co. Ltd., USA). The amount of HEWL adsorbed on BCP was calculated by subtracting the amount of HEWL included in the supernatant liquid after adsorption from the amount of HEWL in its aqueous solution before adsorption. The amount of HEWL was measured at $280 \mathrm{~nm}$ by UV/vis spectrophotometer (UV-1800, Shimadzu Co. Ltd., Japan).

\subsection{Heat Treatment of $B C P$-Adsorbed HEWL}

A requisite amount of $\mathrm{BCP}$-adsorbed HEWL was dispersed in $0.01 \mathrm{M}$ phosphate buffer solution of $\mathrm{pH} 7.0$, the mixture was incubated in a thermostated silicone oil bath at high temperatures for an adequate time, and then the mixture was cooled at $25^{\circ} \mathrm{C}$ for $30 \mathrm{~min}$.

\subsection{Measurement of Remaining Activity of HEWL}

HEWL catalyzes the hydrolysis of the $\beta-1,4$ glycosidic linkage between the $N$-acetylmuramic acid and $\mathrm{N}$-acetylglucosamine components of peptidoglycan in the cell membrane of bacteria. This causes the breakdown and removal of peptidoglycan from the bacterium which results in cell bursting or lysis in natural hypotonic solutions (Illanes, 1999; Noritomi et al., 2011). After the heat treatment, an aqueous solution of BCP-adsorbed $\mathrm{HEWL}$ was cooled in a thermostated water bath at $25^{\circ} \mathrm{C}$ for $30 \mathrm{~min}$. After $350 \mu \mathrm{L}$ of the cooled aqueous solution of BCP-adsorbed HEWL was added to $21 \mathrm{~mL}$ of $0.01 \mathrm{M}$ phosphate buffer solution of $\mathrm{pH} 7$ containing $200 \mathrm{mg} / \mathrm{L}$ Micrococcus lysodeikticus, and then the mixture was incubated at $25^{\circ} \mathrm{C}$ with stirring, the absorbance of the mixuture was periodically measured at $450 \mathrm{~nm}$ by UV/vis spectrophotometer (UV-1800, Shimadzu Co. Ltd.). Bacterial lysis obeys a first order reaction. The lysis rate constant $(\mathrm{k})$ is calculated by

$$
\ln \left(\mathrm{A}^{\mathrm{o}}{ }_{450} / \mathrm{A}_{450}\right)=k \mathrm{t}
$$

where $\mathrm{t}, \mathrm{A}^{\circ} 450$, and $\mathrm{A}_{450}$ are the reaction time, the absorbance of the substrate solution at $450 \mathrm{~nm}$ at $\mathrm{T}=0$, and the absorbance of the substrate solution at $450 \mathrm{~nm}$ at $\mathrm{T}=\mathrm{t}$, respectively. The remaining activity (R. A.) is defined as

$$
\text { R. A. }=100 \times k / k_{o}
$$

where $k_{o}$ and $k$ are the lysis rate constants at $25^{\circ} \mathrm{C}$ of $\mathrm{BCP}$-adsorbed HEWL before and after heat treatment, respectively.

\subsection{Measurements of $\zeta$ Potential and Fourier Transform Infrared (FTIR) Spectroscopy of HEWL}

The $\zeta$ potentials of HEWL were measured by massively parallel-phase analysis light scattering (Möbiu $\zeta$, WYATT Technology Co. Ltd.) 
FTIR measurements of free and BCP-adsorbed HEWL were carried out using a Jasco FT/IR spectrometer model FT/IR-4100. A KBr pellet containing $0.5 \mathrm{mg}$ of free or BCP-adsorbed HEWL powder per $100 \mathrm{mg}$ of $\mathrm{KBr}$ was prepared, and the measurements were performed using 512 scans under $4.0 \mathrm{~cm}^{-1}$ resolution.

\section{Results and Discussion}

\subsection{Characterization of $B C P$ and Adsorption of HEWL on $B C P$}

In the present study, $\mathrm{BCP}$ was obtained by an environmentally benign process. Bamboo waste was pyrolyzed without burn at low temperatures, compared to the conventional charcoal production. Accordingly, carbon dioxide emission was reduced, the energy cost was low, and the atom economy of carbon was high.

Figure 1 shows the scanning electron micrograph of $\mathrm{BCP}$. The surface state of $\mathrm{BCP}$ was almost smooth under the magnification measured in the present study. On the other hand, the specific surface area of BCP was $317 \mathrm{~m}^{2} / \mathrm{g}$, which was similar to that of a conventional wood charcoal. The pore diameter peak of BCP was $0.8 \mathrm{~nm}$. This size is much smaller than that of HEWL since the size of HEWL is $4.5 \times 3.0 \times 3.0 \mathrm{~nm}$ (Jollès, 1996).

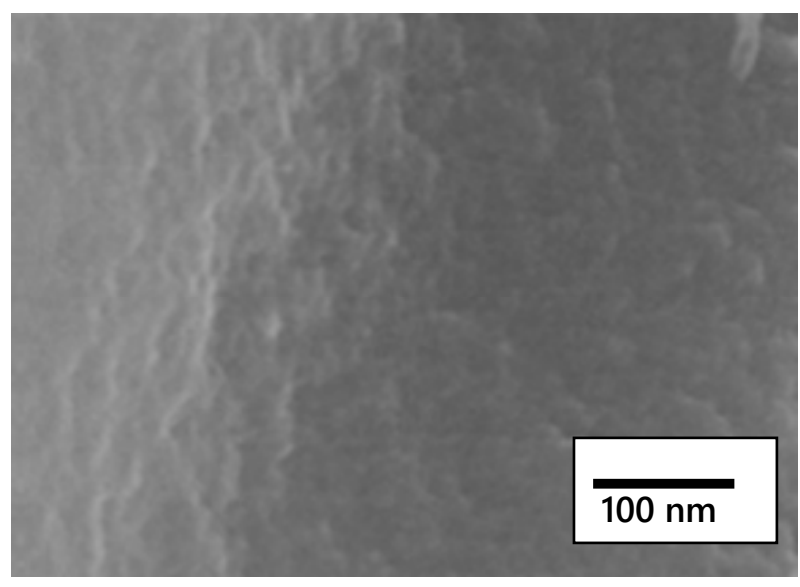

Figure 1. SEM image of bamboo charcoal powder (BCP)

As seen in Figure 2, carbonyl, carboxyl, and phenolic groups were detected by solid-state DD/MAS ${ }^{13} \mathrm{C}-\mathrm{NMR}$ spectroscopy. Moreover, on the measurement of X-ray photoelectron spectroscopy (XPS) of BCP, C-O, O-C-O, $\mathrm{C}=\mathrm{O}, \mathrm{COOH}, \mathrm{C}-\mathrm{N}$, and so on were detected. Functional groups containing oxygen atoms are formed by thermal decomposition of cellulose and hemicellulose at $500^{\circ} \mathrm{C}$, and functional groups decrease with increasing carbonization temperature (Asada et al., 2002; Nishimiya et al., 1998). Those functional groups are useful for adsorbing enzymes to solid carriers firmly (Zdata et al., 2018).

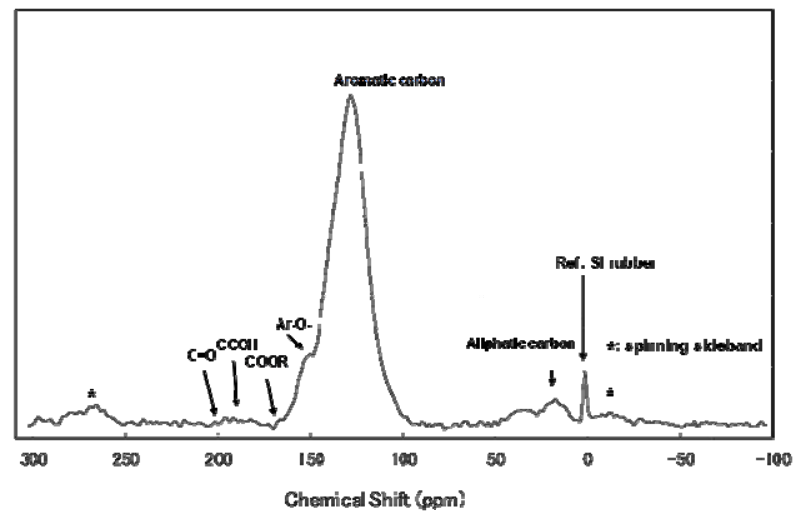

Figure 2. DD/MAS ${ }^{13} \mathrm{C}-\mathrm{NMR}$ spectrum of bamboo charcoal powder (BCP)

HEWL was adsorbed on BCP at $9 \mu \mathrm{mol} / \mathrm{g}$. When it is assumed that HEWL molecules in the end-on orientation contact $\mathrm{BCP}$ with their major axis perpendicular to the surface of $\mathrm{BCP}$ or those in the side-on orientation contact $\mathrm{BCP}$ with their minor axis perpendicular to the surface of $\mathrm{BCP}$, the coverage of end-on was $12 \%$ while that of 
side-on was $19 \%$. Consequently, it is suggested that HEWL is adsorbed at monolayer. Moreover, the $\zeta$-potential of HEWL was $6.2 \mathrm{mV}$ whereas that of BCP was $-53.5 \mathrm{mV}$ at $\mathrm{pH} 7$, where the adsorption was carried out. These results indicate that the electrostatic interaction between the positively-charged HEWL and the negatively-charged surface of BCP mainly contributes to the adsorption of HEWL on BCP.

\subsection{Conformation of BCP-Adsorbed HEWL}

Three dementional structure of enzymes consists of secondary structures such as $\alpha$-helix and $\beta$-sheet. In order to assess the structural change of HEWL by the adsorption of HEWL on BCP, we have measured the FTIR spectra of HEWL before and after the adsorption of HEWL on BCP.

Figure 3 shows the FTIR spectra of free and BCP-adsorbed HEWL. The spectral pattern of HEWL varied before and after the adsorption in the region of amide $\mathrm{I}\left(1700-1600 \mathrm{~cm}^{-1}\right)$, which is due entirely to the $\mathrm{C}=\mathrm{O}$ stretch vibrations of the peptide linkages (Surewicz \& Mantsch, 1988). The band at ca. $1650 \mathrm{~cm}^{-1}$ is assignable to $\alpha$-helix while the band at ca. $1680 \mathrm{~cm}^{-1}$ is assignable to intramolecular $\beta$-sheet. In Table 1 , the ratio of the absorbance at $1681 \mathrm{~cm}^{-1}$ to the absorbance at $1647 \mathrm{~cm}^{-1}$ of BCP-adsorbed HEWL was different from that of free one. This result indicates that the secondary structure of HEWL is altered to some extent by the adsorption of HEWL on BCP.

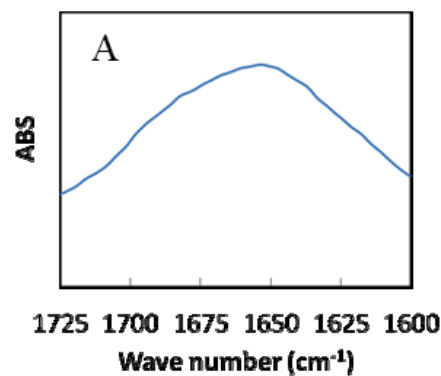

Figure 3. (A) FTIR spectrum of free HEWL.

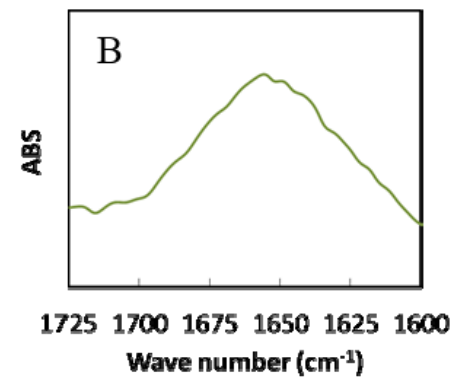

(B) FTIR spectrum of BCP-adsorbed HEWL

Table 1. Ratio of the absorbance at $1681 \mathrm{~cm}^{-1}$ to the absorbance at $1647 \mathrm{~cm}^{-1}\left(\mathrm{ABS}_{1681} / \mathrm{ABS}_{1647}\right)$ of free and biochar-adsorbed HEWL provided by the FTIR measurement

\begin{tabular}{ll}
\hline Samples & $\mathrm{ABS}_{1681} / \mathrm{ABS}_{1647}(-)$ \\
\hline Free HEWL & 0.88 \\
BCP-adsorbed HEWL & 0.69 \\
\hline
\end{tabular}

\subsection{Influence of Incubation Temperature on Remaining Activity of BCP-Adsorbed HEWL}

Modest heating causes proteins such as enzymes dissolved in an aqueous solution to be denatured and inactivated by the unfolding of proteins due to the disruption of weak interactions such as ionic bonds, hydrogen bonds, and hydrophobic interactions, which are prime determinants of protein tertiary structures (Klivanov, 1983; Creighton, 1989; Noritomi et al., 2011).

Figure 4 shows the relationship between the remaining activities of free and BCP-adsorbed HEWL and the incubation temperature after the incubation for $30 \mathrm{~min}$. As seen in the figure, the dependence of the remaining activity on the incubation temperature exhibited the sigmoid curve. The remaining activity of free HEWL gradually dropped from $60^{\circ} \mathrm{C}$, and dramatically decreased from $70^{\circ} \mathrm{C}$ while the remaining activity of $\mathrm{BCP}$-adsorbed HEWL descended from $75^{\circ} \mathrm{C}$, and still exhibited $21 \%$ at $90^{\circ} \mathrm{C}$, which was about thirty times larger than that of free one. Accordingly, the thermal denaturation curve of BCP-adsorbed HEWL was shifted to high temperatures, compared to that of free one. 


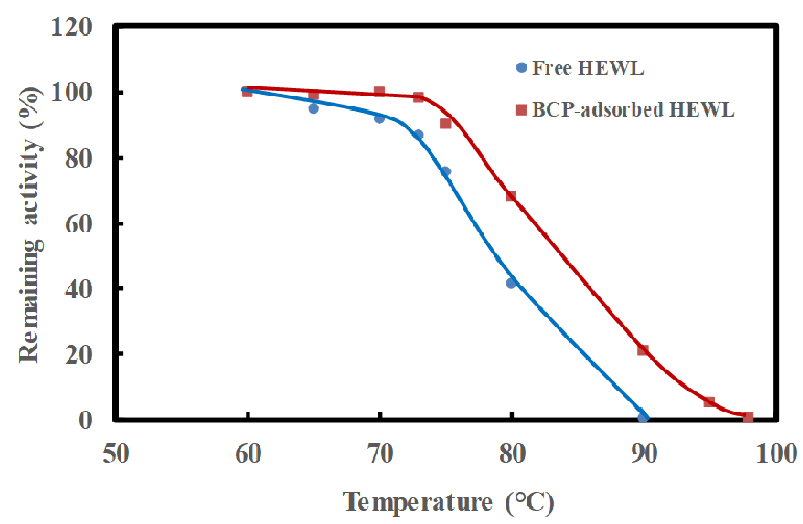

Figure 4. Thermal denaturation curves of free and BCP-adsorbed HEWL. The aqueous solution of free or $\mathrm{BCP}$-adsorbed HEWL was incubated at a predetermined temperature for $30 \mathrm{~min}$

\subsection{Influence of Incubation Time on Remaining Activity of BCP-Adsorbed HEWL at High Temperatures}

In general, the denaturation of enzymes progresses with the incubation time at high temperatures (Creighton, 1989). Figure 5 shows the time courses of remaining activities of free and $\mathrm{BCP}$-adsorbed $\mathrm{HEWL}$ at $90^{\circ} \mathrm{C}$. The remaining activities of free and BCP-adsorbed HEWL decreased with increasing the incubation time. Free HEWL solution immediately became turbid due to the aggregation of denatured enzymes as soon as the incubation started. On the other hand, no aggregation of enzymes was observed during the incubation in the solution of BCP-adsorbed HEWL, indicating that enzymes are firmly adsorbed on $\mathrm{BCP}$ even at high temperatures. In the figure, the relationship between the remaining activities of free and BCP-adsorbed HEWL and the incubation time could be correlated by first-order kinetics. As shown in Table 2, the half-life of BCP-adsorbed HEWL was more than three times longer than that of free one. Accordingly, the result indicates that the heat stress tolerance of HEWL is markedly enhanced by the adsorption of HEWL on BCP.

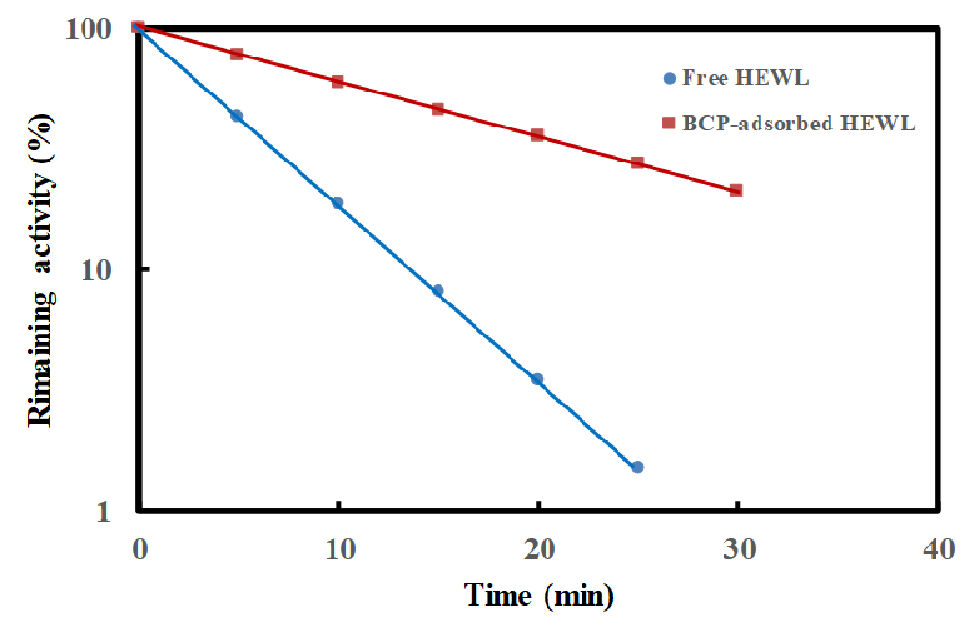

Figure 5. Time courses of remaining activities of free and BCP-adsorbed HEWL at $90^{\circ} \mathrm{C}$

Table 2. Rate constants and half-lives of denaturation of HEWL at $90^{\circ} \mathrm{C}$

\begin{tabular}{lll}
\hline Samples & Rate constant $\left(\mathrm{min}^{-1}\right)$ & Half life $(\mathrm{min})$ \\
\hline Free HEWL & 0.17 & 4 \\
BCP-adsorbed HEWL & 0.052 & 13 \\
\hline
\end{tabular}




\section{Conclusions}

We have demonstrated that BCP remarkably improves the stability of HEWL at high temperatures as an enzyme carrier. HEWL was firmly adsorbed on BCP even at high temperatures. The conformation of HEWL changed to some extent by the adsorption of HEWL on BCP. The denaturation curve of BCP-adsorbed HEWL was shifted to high temperatures, compared to that of free one. The half-life of BCP-adsorbed HEWL was more than three times longer than that of free one at $90^{\circ} \mathrm{C}$. Accordingly, the results indicate that $\mathrm{BCP}$ is suitable as an enzyme carrior for the heat stress tolerance of enzymes.

\section{Conflict of interests}

The authors declare that there is no conflict of interests regarding the publication of this paper.

\section{References}

Ahern, T. J., \& Klibanov, A. M. (1985). The mechanism of irreversible enzyme inactivation at $100^{\circ} \mathrm{C}$. Science, 228 , $1280-1284$.

Asada, T., Ishihara, S., Yamane, T., Toba, A., Yamada, A., \& Oikawa, K. (2002). Science of bamboo charcoal: study on carbonizing temperature of bamboo charcoal and removal capability of harmful gases. Journal of Health Science, 48, 473-479.

Bailey, J. E., \& Ollas, D. F. (1986). Biochemical Engineering Fundamentals (2nd ed.). McGraw-Hill.

Buchholz, K., Kasche, V., \& Bornscheuer, U. T. (2012). Biocatalyst and Enzyme Technology (2nd ed.). Wiley-Blackwell.

Creighton, T. E. (1989). Protein Function: Practical Approach (1st ed.). IRL Press.

Heinzle, E., Biwer, A. P., \& Cooney, C. L. (2006). Development of Sustainable Bioprocesses, Modeling and Assessment. John Wiley \& Sons, Ltd.

Illanes, A. (1999). Stability of biocatalysts. Electro. J. Biotechnol., 2, 1-9.

IPCC, Climate Change 2014. (2014). Synthesis Report, Intergovernmental Panel on Climate Change (IPCC), Geneva, Switzerland.

Jollès, P. (1996). Lysozymes: Model Enzymes in Biochemistry and Biology (1st ed.). Birkhäuser Verlag.

Klibanov, A. M. (1983). Stabilization of enzymes against thermal inactivation. Adv. Appl. Microbiol., 29, 1-28.

Leech, D., Kavanagh, P., \& Schuhmann, W. (2012). Enzymatic fuel cells: Recent progress. Electrochimica Acta, $84,223-234$.

Nishimiya, K., Hata, T., Imamura, Y., \& Ishihara, S. (1998). Analysis of chemical structure of wood charcoal by X-ray photoelectron spectroscopy. Journal of Wood Science, 44, 56-61.

Nohara, D., Mizutani, A., \& Sakai, T. (1999). Kinetic study on thermal denaturation of hen egg-white lysozyme involving precipitation. J. Biosci. Bioeng., 87, 199-205.

Noritomi, H., Minamisawa, K., Kamiya, R., \& Kato, S. (2011). Thermal stability of proteins in the presence of aprotic ionic liquids. J. Biomedical Sci. Eng., 4, 94-99.

Noritomi, H., Nishigami, J., Endo, N., Kato, S., \& Takagi, S. (2018). Effect of solvent on catalysis of protease adsorbed on biochar in organic media. J. Materials Sci. Research, 7, 46-52.

Noritomi, H., Nishigami, J., Endo, N., Kato, S., \& Uchiyama, K. (2017a). Organic solvent-resistant properties of proteins adsorbed onto biomass charcoal powder. International J. GEOMATE, 12, 140-145.

Noritomi, H., Nishigami, J., Endo, N., Kato, S., \& Uchiyama, K. (2017b). Influence of water activity on protease adsorbed on biochar in organic solvents. J. Materials Sci. Research, 6, 96-102.

Olivier, J. G. J., Muntean, M., \& Peters, J. A. H. W. (2017). Trends in Global CO2 Emissions: Report.

Sheldon, R. A., \& Woodley, J. M. (2018). Role of biocatalysis in sustainable chemistry. Chem. Rev., 118, 801-838.

Silwana, B., Horst, C. V. D., \& Iwuoha, E. (2014). Aerometric determination of cadmium, lead, and mercury metal ions using a novel polymer immobilized horseradish peroxidase biosensor system. J. Environmental Sci. Health Part A, 49, 1501-1511.

Straathof, A. J. J. (2014). Transformation of biomass into commodity chemicals using enzymes or cells. Chem. Rev., 114, 1871-1908. 
Surewicz, W. K., \& Mantsch, H. H. (1988). New insight into protein secondary structure from resolution-enhanced infrared spectra. Biochim. Biophys. Acta, 952, 115-130.

Tanaka, A., Isomae, K., \& Gokano, M. (2003). Air cleaning filter. US Patent, 6579352.

Zdata, J., Meyer, A. S., Jesionowski, T., \& Pinelo, M. (2018). A general overview of support materials for enzyme immobilization: characteristics, properties, practical utility. Catalysts, 8, 92-118.

\section{Copyrights}

Copyright for this article is retained by the author(s), with first publication rights granted to the journal.

This is an open-access article distributed under the terms and conditions of the Creative Commons Attribution license (http://creativecommons.org/licenses/by/4.0/). 